\title{
IMPROVEMENT OF THE CHERRY VARIETIES USED IN THE NETHERLANDS
}

\author{
C. J. GERRITSEN \\ Institute of Horticultural Plant Breeding, Wageningen, Netherlands \\ Received 28 Jan. 1956
}

CONTENTS Page

Introduction . . . . . . . . . . . . . . . . . . . . . 101

Regrouping the list of recommended varieties . . . . . . . . . . . . 102

Collecting varieties from the Netherlands and from abroad . . . . . . . . . 106

Morphological investigations and type selection . . . . . . . . . . . . . 106

Breeding techniques ... . . . . . . . . . . . . . . . . 108

Evaluation of unknown varieties and newly produced seedlings . . . . . . . . 110

Trials of collected varieties . . . . . . . . . . . . . . . . . . . 111

Production of Prunus avium seedlings . . . . . . . . . . . . . . . . 112

Production of better Duke varieties . . . . . . . . . . . . . . . . . . 112

Summary. . . . . . . . . . . . . . . . . . . . . . 115

Samenvatting . . . . . . . . . . . . . . . . . 115

References... . . . . . . . . . . . . . . 116

\section{INTRODUCTION}

The cherry is a fairly important fruit crop in the Netherlands. As regards its acreage it ranks third with 4321 ha (1953) i.e. $7 \%$ of the total fruit area (apple $66 \%$, pear $21 \%$, plum $6 \%$ ). From 1950 to 1953 arrivals at the auctions averaged 16.7 million kg with a value of $7,850,000$ - guilders i.e. respectively 3.7 and $8.5 \%$ of the total of the 4 fruit crops (apple 63.4 and $59.9 \%$, pear 27.1 and $25.8 \%$, plum 5.8 and $5.8 \%$ ).

Nowadays it appears that the cherry industry is on the decline: many cherries are being grubbed and very few planted. This tendency, which started before 1940, was not so noticeable during or just after the war; in the last 5 years, however, it has become much more manifest.

In 1947 we started extensive research on the cherry (culture, varieties, outlet, etc.). The results have shown that much can still be done to give the cherry industry a sounder basis so that decline may be turned into progress (3). The same conclusion was reached at a meeting held at the Institute of Horticultural Plant Breeding in 1952. This meeting was attended by persons concerned with the growing, commercialization and processing of cherries and by the staff of the Horticultural Advisory Service (1). It was evident that not only improved cultural measures but especially replanting with better varieties would have a favourable effect on the production costs, prices and yields, thus increasing the productivity of the cherry industry. 


\section{J. GERRITSEN}

These improved varieties should have higher standards than the old varieties of the following qualities:

Picking quality (dependent on the fruit arrangement, and whether a variety is cropping evenly);

Disease resistance (bacterial canker, brown rot, virus diseases, silver leaf);

Susceptibility to poor weather conditions;

Fertility;

Fruit size;

Transport and storage qualities;

Pollination requirements (self-compatible or intercompatible with the leading varieties);

Time of ripening (favourable ripening intervals).

To obtain such varieties a start was made with the study of the most important varieties occurring in the Netherlands. This research has already produced important practical results.

In addition many varieties were collected from the Netherlands and from abroad, as many of them were likely to prove of great value.

Later, a breeding programme was started. The following examples show that good gene material is available:

a. Three times as many $\mathrm{kg}$ of fruit are picked from Schneiders Späte Knorpelkirsche per time unit as from Früheste der Mark.

$b$. With Pater van Mansfeld up to $100 \%$ of the trees are lost in 10 to 15 years, due to bacterial canker; in Inspecteur Löhnis the loss is mostly nil during the same period.

c. The so-called "Harde Kassins Frühe" is very susceptible to rain; in many years it cannot be picked on account of the high percentage of cracked fruits; on average the percentage in Wijnkers is less than one-fifth of that in Kassins.

$d$. The fertility of Morel is three times that of Frühe Französische.

Some of these investigations are being carried out in collaboration with other research workers. Unless stated otherwise, they belong to the staff of the Institute of Horticultural Plant Breeding.

\section{REGROUPING THE LIST OF RECOMMENDED VARIETIES}

The first step towards improvement was a study of important commercial varieties grown in Holland. This led to important changes in the list of recommended varieties, and subsequently in the planting of varieties (Table 1), as the majority of the growers act on the recommendations in this list.

So far there have been three categories of recommendation:

a. Recommended varieties;

b. Additional varieties;

c. Promising varieties.

Of nine varieties that had been classified as recommended for many years, two were discarded in the last issue as being no longer of value and seven were placed in a new category of local importance only. Abesse de Mouland $(=$ Bastaarddikke $=$ Eisdense) and Varikse Zwarte were discarded. Early Rivers, Klerk, Pater van Mansfeld 
TAble 1. SURVEY OF THE VARIETIES DesCribed IN tHE LAST FoUR ISSUES OF THE NETHERLANDS LIST OF FRUIT VARIETIES $(1938 / 39,1943,1948,1954)$, AND OF THE CLASSES UNDER WHICH THEY HAVE BEEN GROUPED.

\begin{tabular}{l}
\hline Variety \\
Abesse de Mouland (Bastaarddikk \\
Early Rivers \\
Klerk \\
Pater van Mansfeld (Markies) \\
Mierlose Zwarte (Udense Zwarte)
\end{tabular}

\section{Udense Spaanse}

Varikse Zwarte

Meikers

\section{Morelle}

Dikke Loen (Kernielse)

Drogans Gelbe Knorpelkirsche

Elton

Hollander

Wijnkers

Zeeuwse Zoete Morel

Bruine Vleeskers (Zwarte of Bruine Spaanse)

Kentish (Rode Waalse)

Knolkers

0 = recommended varieties; 1954
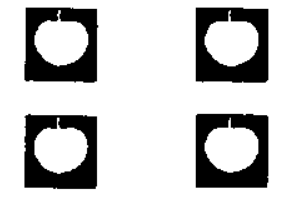

$\square$

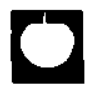

0

0

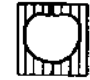

0

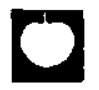

(m)

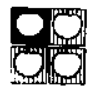

$\longrightarrow$

$C_{0}^{1}$
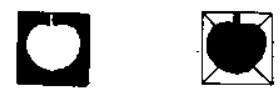

C
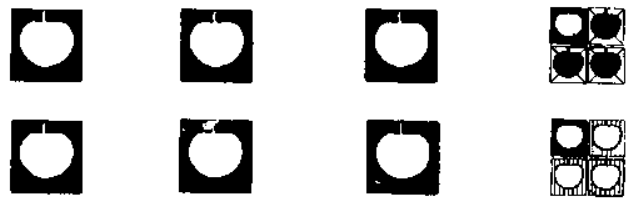

एव:

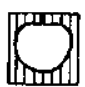

(1)

Drif
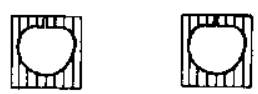

(II)

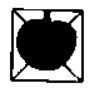

(P)
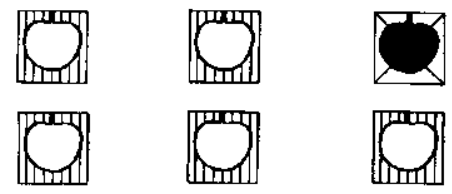

त्m
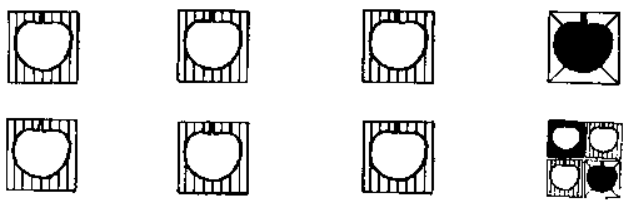

(3)
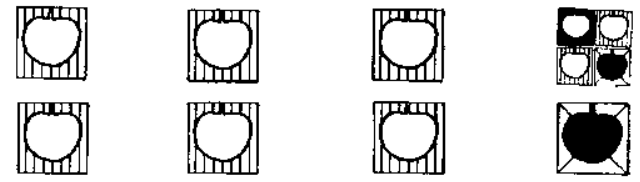

(1)
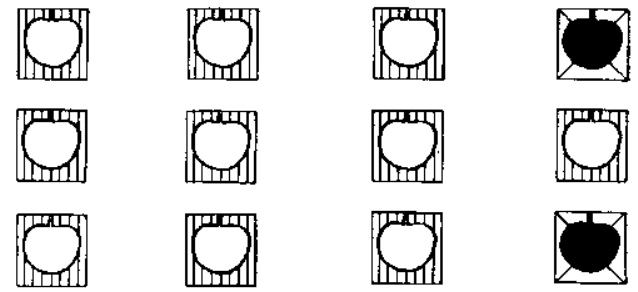

(1)
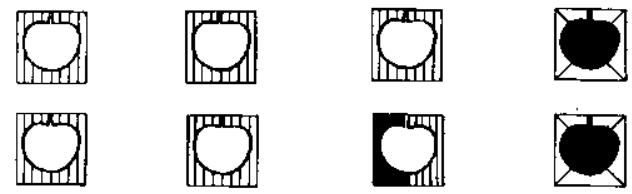
TABLE 1 (continued)

Variety
Westerleese Kriek (Cerise de Schaerbeek,
Wye Morello)
Beekse Late
Schneiders Späte Knorpelkirsche (Hedelfinger
Riesenkirsche falso)
Koningskers
Molenkers
Wilhelmina

Eierkriek

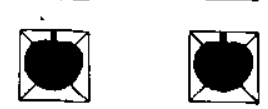

Vroege van Werder
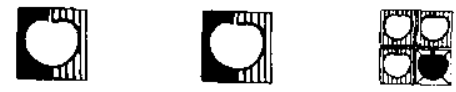

Rijkmaker
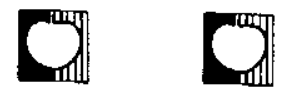

$r$
$k$

Früheste der Mark

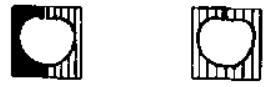

Frühe Französische (Lamotte)

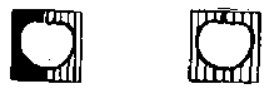

Guigne d'Annonay (Vroege van Spithoven)

"Kassins Frühe" (Zachte Kassin)
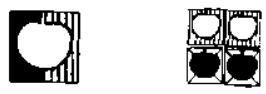

Beierlander
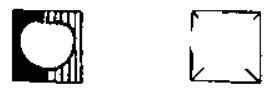

Asdonkse (No. 501)

Frans Meylingkers

Bigarreau Napoléon (Gascogner, Rouaan)

$\square=$ promising varieties and $\quad=$ varieties which are not recommended. 
(= Markies), Mierlose Zwarte (= Udense Zwarte), Udense Spaanse, Meikers and Morel were classified as varieties of local importance.

Of the ten additional varieties six were reclassified as not recommended (Drogans Gelbe Knorpelkirsche, Elton, Hollander, Zeeuwse Zoete Morel, Kentish = Rode Waalse, and Knolkers), one as promising (Westerleese Kriek = Cerise de Schaerbeek = Wye Morello), and two as of local importance (Dikke Loen $=$ Kernielse, and Wijnkers). Only Bruine Vleeskers $=$ Zwarte Spaanse $=$ Bruine Spaanse was kept in the category of additional varieties.

Of the eight promising varieties in the old lists $(1939,1943)$ four were deleted, one was reclassed as an additional variety, and three were placed in the group of varieties of local importance. In 1948 five varieties were newly listed as promising; in 1954 three of them were reclassed as additional varieties, one was reclassed as a variety of local importance, and one was deleted. In 1954 three varieties were newly listed, one as additional, one as promising, and one as of local importance.

The 7 th edition (1954) is the first to include local stocks (only of cherry), as the demands made on varieties may differ widely with the locality, owing to the different commercial and growing conditions. Thus in one locality a variety may belong to group while in others it should be placed in

TABLE 2. VARIETIES RECOMMENDED FOR GROWING IN THE NETHERLANDS, ARRANGED IN THE ORDER OF THEIR MATURITY; AS A RULE A HIGH MARK INDICATES A FAVOURABLE DEVELOPMENT OF THE CHARACTER IN QUESTION; $\mathbf{s}==$ sufficient, $\mathrm{i}=$ insufficient

\begin{tabular}{|c|c|c|c|c|c|c|c|}
\hline Varieties & $\begin{array}{l}\text { Time of } \\
\text { ripening in } \\
\text { days after } \\
\text { Früheste der } \\
\text { Mark }\end{array}$ & Fertility & $\begin{array}{c}\text { State } \\
\text { of } \\
\text { health }\end{array}$ & Taste & $\begin{array}{c}\text { Resistance } \\
\text { to rain }\end{array}$ & $\begin{array}{l}\text { Resistance } \\
\text { to brown } \\
\text { rot }\end{array}$ & Size \\
\hline I. Früheste der Mark & 0 & 5 & 3 & 1 & 3 & $s$ & $1-2$ \\
\hline 2. Frühe Französische & 3 à 7 & 3 & 5 & $3-4$ & 4 & s & 2 \\
\hline 3. Guigne d'Annonay & 9 à 12 & 4 & 5 & $2-3$ & 4 & $\mathbf{s}$ & 2 \\
\hline 4. Asdonkse & 9 à 12 & 4 & 5 & 4 & 4 & s & $2 \frac{1}{2}-3$ \\
\hline 5. Early Rivers type & & & & & & & \\
\hline Alf heim & 10 à 14 & 4 & 3 & 4 & 4 & s & $3-3 \frac{1}{2}$ \\
\hline 6. Kassins Frühe & 10 à 14 & 4 & 5 & $2-3$ & 4 & s & $2 \frac{1}{2}-3$ \\
\hline 7. Vroege van Werder & 21 à 24 & 5 & 2 & 3 & 3 & $s$ & $2 \frac{1}{2}-3 \frac{1}{2}$ \\
\hline 8. Pater van Mansfeld & 24 à 28 & 5 & 2 & $4-5$ & 2 & s & $2 \frac{1}{2}-3 \frac{1}{2}$ \\
\hline 9. Dubbele Meikers & 20 à 35 & 5 & 5 & $4-5$ & 4 & $\mathrm{i}$ & $2-3$ \\
\hline 10. Kernielse & 26 à 30 & 4 & 4 & $3-4$ & 3 & $\mathbf{s}$ & $3-3 \frac{1}{2}$ \\
\hline 11. Mierlo'se Zwarte & 30 à 33 & 4 & 5 & 3 & 3 & $\mathrm{~s}$ & $2 \frac{1}{2}-3$ \\
\hline 12. Wijnkers & 31 à 35 & 4 & 3 & $4-5$ & 5 & $s$ & $2 \frac{1}{2}-3 \frac{1}{2}$ \\
\hline 13. Inspecteur Löhnis & 31 à 35 & 5 & 5 & $4-5$ & 2 & $\mathrm{i}$ & $2 \frac{1}{2}-3 \frac{1}{2}$ \\
\hline \multicolumn{8}{|l|}{ 14. Schneiders Späte } \\
\hline Knorpelkirsche & 33 à 40 & 3 & 5 & 4 & 2 & $\mathrm{i}$ & $4 \frac{1}{2}-5$ \\
\hline 15. Bigarreau Napoléon & 33 à 40 & 5 & 2 & 3 & 2 & s & $4-5$ \\
\hline 16. Udense Spaanse & 38 à 42 & 4 & 5 & $2-3$ & 3 & i & $4-5$ \\
\hline 17. Bruine Vleeskers & 40 à 44 & 5 & 4 & $2-3$ & 2 & $i$ & $3-5$ \\
\hline 18. Koningskers & 40 à 44 & 4 & 2 & $3-4$ & 2 & s & $4-5$ \\
\hline 19. Frans Meylingkers & 44 à 47 & 4 & 4 & $2-3$ & 3 & s & $2 \frac{1}{2}-3$ \\
\hline 20. Klerk & 44 à 47 & 3 & 4 & 2 & 3 & s & $1-1 \frac{1}{2}$ \\
\hline 21. Morelle & 45 à 60 & 5 & 5 & sour & 5 & i & $2 \frac{1}{2}-3 \frac{1}{2}$ \\
\hline 22. Westerleese Kriek & 45 à 60 & 5 & 5 & sour & 5 & s & 1 \\
\hline
\end{tabular}




\section{J. GERRITSEN}

The list of 1954 (the latest) includes 22 cherry varieties. They are given in Table 2, together with an indication of some of their characters. In the list these characters are described in greater detail and more accurately than in previous editions (in which little could be said of important characters such as fruit size and time of ripening, and of pollen compatibility).

This new list is an important step forward, but further improvement seems possible. Therefore many varieties were collected in the hope of finding some promising varieties among the selections made by other workers; in addition many crosses were made in order to produce selections combining as many valuable characters as possible.

\section{COLLECTING VARIETIES FROM THE NETHERLANDS AND FROM ABROAD}

The material collected from the Netherlands includes the commonly grown varieties, with strains of these varieties (mutations?), local varieties and chance seedlings which we encountered in nurseries, orchards and gardens.

A total of about 400 varieties and unnamed selections were imported up to the autumn of 1955. The majority of these came from Belgium, Germany, England, France and the U.S.A.; a good many also from Canada, Denmark, Sweden and Switzerland. The new selections and varieties released yearly by experiment stations and breeders are being collected as soon as possible in order to test them under Dutch conditions.

In order to restrict the number of older varieties, introductions were only made from countries where the climate is similar to that of the Netherlands. Varieties which performed well in their country of origin, as well as less satisfactory varieties were introduced; the climatic conditions and growing and commercial requirements in many countries often differ so widely from those in the Netherlands that a variety which is considered unsuitable or has passed out of cultivation elsewhere may prove valuable here. Besides it is often very difficult to assess the value of foreign varieties owing to incomplete descriptions and lack of useful data on their times of ripening.

\section{MORPHOLOGICAL INVESTIGATIONS AND TYPE SELECTION}

Many of the collected varieties have been flowering for some years and have fruited at least once, so that many morphological observations could be made. From these it was shown that the cherry nomenclature is very confused. Many varieties received under the same name were far from being identical (for instance Hedelfinger Riesenkirsche), while other varieties carrying different names proved to be identical (for instance Bigarreau de Jaboulay was encountered under the following names: Lyons, Bigarreau de Lyon, Vroege Bigarreau, A 17, A 46, Vroege van Gelmen, Ramon Oliva and Olivar).

This morphological research is being carried out by Mr. E. T. NANNENGA. Within a few years a detailed survey of synonymy (including morphological descriptions) may be expected.

It was found to be necessary to include the varieties occurring in the Netherlands in the morphological investigations, as research on the cultural value and pollination of varieties is not possible if the varieties cannot be recognized. It has often happened 


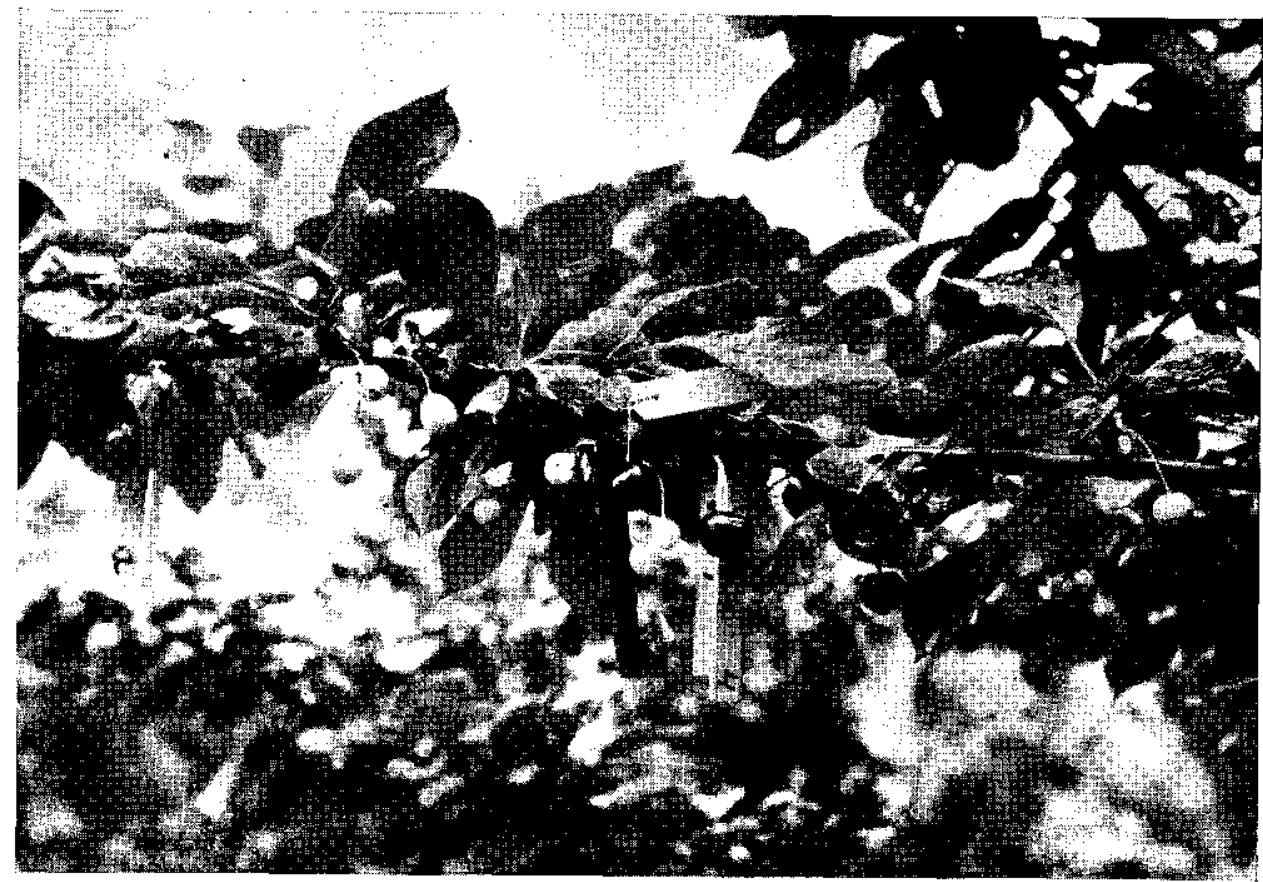

Fig. 1. Ripe may dukE and GReEN VOlgers on the Same branch

that a certain variety that did well in one locality give poor results in another; further research then revealed that the name was the only thing these varieties had in common! With many varieties the local or commonly used names could be replaced by names correct according to nomenclature.

It is not always possible to make a clear morphological distinction between the varieties, notwithstanding the fact that they show clear physiological differences which may be of great practical value, such as differences in disease susceptibility, fruit size or time of ripening. In many cases these differences may be incidental (due to certain circumstances, for instance type of soil, rootstock used) or they may be reproducible (mutations, or varieties resembling each other very closely but originating from hybridization). This can only be found out by means of prolonged and expensive trials in which the types must be grafted on rootstocks which have been propagated vegetatively, and be planted in a number of replications. In general this expensive research has been avoided, and a cheaper solution chosen instead: the Netherlands General Inspection Service for Arboriculture (N.A.K.-B) certifies as mother trees for the supply of scionwood to nurserymen only those trees which belong to the apparently best type. Consequently only trees of that type are planted, and nothing is lost if the differences prove to have been incidental.

"Types" that are difficult to distinguish occur in the following varieties: Früheste der Mark, Frühe Französische, Early Rivers, Kernielse, Mierlose Zwarte, Meikers ( = May Duke == Anglaise hâtive = Rote Maikirsche), Varikse Zwarte, Wijnkers, Bigarreau Napoléon, Abesse de Mouland, and others. 
With one of these varieties, namely May Duke, the above "solution" is only effective to a limited extent. This is because of some kind of instability of the fruits, so that on one tree numerous variations in fruit shape and ripening may be encountered. The practical growers speak of May Dukes (which are further divided as early, midseason and late types, viz. Moortjes, May Dukes and Boskopers) and Volgers. The latter grow on the same trees as the May Duke but mature up to 3 weeks later and also differ from them in shape, size, taste, and shape of the stone. Closer observations have shown that with respect to maturity and fruit shape various intermediate forms are encountered on one and the same tree; in addition, the extent to which Volgers are produced varies from year to year. Consequently if a certain good type should be selected, the same phenomena would again appear to a greater or less extent. The question now is whether constant types can be found; this depends on the cause of the phenomenon. If the variations are caused by a virus disease, as some people think, it should be possible to find such types. Another supposition is that the May Duke is a chimaera. Extensive research into this question is being carried out.

As soon as this point has been clarified selection as requested by the practical growers may be possible. Then the growers would have to be supplied with varieties which ripen evenly, and follow each other in picking time. In addition such varieties should possess the good quality of the May Dukes and Volgers.

\section{BREEDING TECHNIQUES}

The first series of crosses were all carried out by hand, at first in the orchards of growers, but later this was done in our own trial fields. If flowering was not uniform, some pollen was stored or branches of the later flowerer were forced to bloom. Pollen was not stored until the next season. Crosses that proved incompatible were discarded.

The best pollination technique was as follows: Remove (not more than 4 days before the opening of the flowers) the calyx, corolla and stamens by tearing the calyx off all round at the broadest spot (this is done with a pair of forceps); pollinate immediately or during the 5 subsequent days (when the stigma is sufficiently sticky) taking special care to dust each stigma with a sufficient amount of pollen; pollination is readily done with a flower from which the style and petals have been removed; if much pollen is available, it may be advisable to collect it and to pollinate with a fine brush; bagging is not necessary, provided the branches of "stripped" flowers cannot be blown against other branches.

In spite of the elimination of incompatible crosses and the development of an effective and rapid pollination technique, the labour requirement in relation to the numbers of seedlings obtained remained very high. Apart from the weather conditions which may occasionally play a part, this is mainly due to the fact that not more than one seed can be harvested per pollinated flower, and that in a number of seedlings many of the embryos abort in the seeds.

Therefore, for crosses that can be carried out for a number of consecutive years, and for others of which appreciable numbers of seedlings are wanted, trees have been grown on in pots. Before the opening of the flowers these trees are placed in pairs in insectproof isolation cages in which pollination is carried out by "clean" bees. This is only possible for the sweet cherry, as it is entirely self-incompatible; in the other cases 
FIG. 2

ABNORMAL GROWTH OF A PLANT GROWN UP WITH THE AID OF EMBRYO-CULTURE (LEFT); NO TERMINAL BUD OCCURS BUT THERE ARE LATERAL BUDS AS APPEARS FROM THE PHOTOGRAPH RIGHT
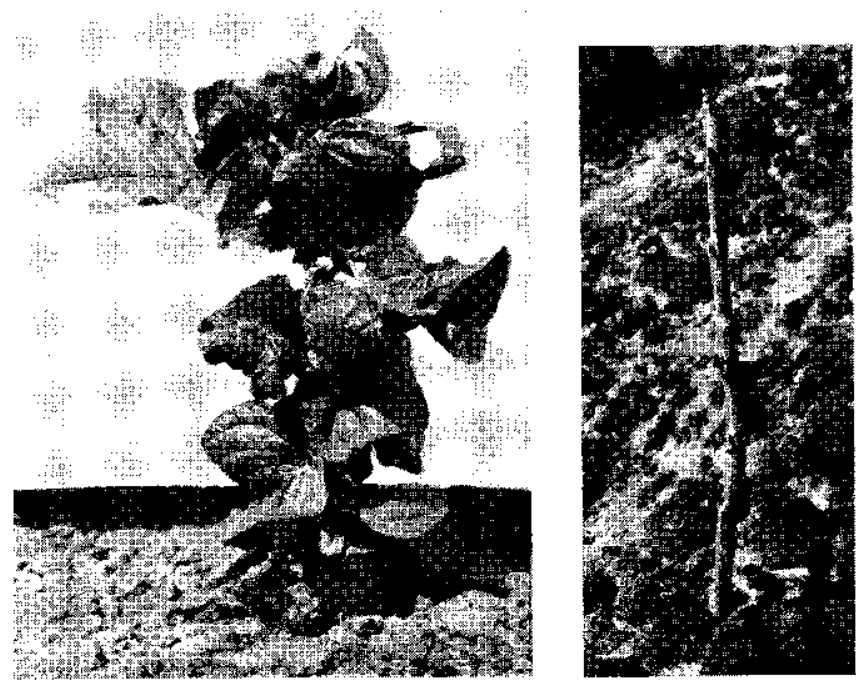

the calyx has to be removed so that the amount of labour saved is less. There are other advantages, however, as for instance a greatly reduced dependence on the weather conditions and simpler control of flowering. In addition it may be possible to eliminate pollen incompatibility under such controlled conditions. Research in this direction is carried out by $\mathrm{Mr}$. $\mathrm{KOH}$ YаM OH.

Incompatibility may also be eliminated by the method of LewIS (10) in which $\mathrm{X}$-ray treatment is given to the flower buds. If important combinations should really prove to be incompatible, even at lower temperatures or when applying growth substances or other methods, it would certainly be worth while trying this treatment.

In many cases the germination percentage of the seeds is low, even when properly stored and after-ripened (for at least 3 months at a temperature of $5{ }^{\circ} \mathrm{C}$ or less). To obtain a greater number of seedlings, embryo culture has been used; methods and results will be discussed in detail in a later paper (2) by the present writer together with Mr. J. P. BraAk.

When plants have been grown by means of embryo culture, it often appears to be difficult to keep them growing, or to re-start growth; some phenomena of abnormal growth also appear. Therefore Mr. L. SMEETs has carried out research on the possibilities of influencing growth and abnormal phenomena by controlling day length or temperature or both, for it is of the utmost importance to keep as many of the plants alive as possible, and to make them develop as soon as possible into healthy, fruiting plants. In addition it may be possible to shorten the "juvenile phase" of the seedlings so that the plants come into bearing earlier (12).

Dukes are hybrids of Prunus cerasus and $P$. avium; they are tetraploid. $P$. cerasus is also tetraploid, but $P$. avium is diploid. In order to make new Dukes, material of $P$. avium is being made tetraploid by Mr. A. E. ZeILINGA. Colchicine treatment of seed would be the simplest way. But treatment of good cultivated varieties of $P$. avium is preferred, as they nearly always have greater cultural value than seedlings and are expected to flower earlier, because the original material was ripe for flowering. 


\section{J, GERRITSEN}

This will also enable us to study the influence of chromosome doubling on selfincompatibility and yield of $P$. avium varieties. Yield is now often too low, owing to insufficient cross-pollination; in the case of full self-compatibility this will no longer play a part, and block planting will be possible (10).

Crosses between other Prunus species are also being explored. This is done in cooperation with Dr. R. PrakKen, professor of genetics in the Agricultural University of Wageningen.

The production of gene mutants $(5,10)$ has not yet been tried, but crossings with pollen of a variety with a mutated S-gene, obtained from Dr. LewIS (9), have already been made.

\section{EVALUATION OF UNKNOWN VARIETIES AND NEWLY PRODUCED SEEDLINGS}

The seedlings obtained by hybridization and the unknown varieties collected from the Netherlands and from abroad are being selected according to the scheme for pome and stone fruits used at the Institute of Horticultural Plant Breeding. This scheme comprises the following consecutive phases:

Nursery (2 years). The young seedlings and grafted trees are planted closely together. Diseased and very weak plants are discarded; in seedlings of important crosses from which only very few viable seeds are obtained, this selection is less rigorous than in the other seedlings. After 2 years the plants are transferred to selection field A.

Selection field $A$. (max. 10 years). The planting distance depends on vigour and precocity. So far the following spacings have been used:

$3 \times 5 \mathrm{~m}$ for seedlings of sweet cherries

$3 \times 4 \mathrm{~m}$ for seedlings with "sour blood"

$2 \times 3 \mathrm{~m}$ for varieties.

During the first fruiting years the seedlings do not produce normal fruits (6). Not until they have borne fruit for a number of years can it be ascertained whether they are really better than the established varieties of identical maturity. As the collected varieties are ripe for flowering they are considered to flower earlier, produce normal fruits earlier, and to be ready for inspection sooner than the seedlings. Hence their closer spacing. In order to reduce the risk of delay which may occur if the trees become diseased or die, 2 trees of each variety are planted. The seedlings with "sour blood" are planted more closely than the sweet cherries, as May Duke and Morel are weaker growing than the sweet varieties, and seedlings with one of these varieties as a parent come earlier into bearing.

In selection field A special attention is paid to the following characters: time of ripening, colour, fruit size, stone size, taste, and resistance to bad weather conditions before and during maturity. Unfruitful or diseased specimens and those which produce very small fruits or have a poor taste may, even in the seedlings, be removed before the normal fruits are produced. Promising seedlings or varieties that may prove valuable as parents are maintained.

Selection field $B$ is destined for promising seedlings and varieties from selection field A; also for foreign and local varieties which are known to have many favourable characters. For comparison a number of good standard varieties are also included. 
Fig, 3. EXTREME FERTILITY OF A SEEDLING

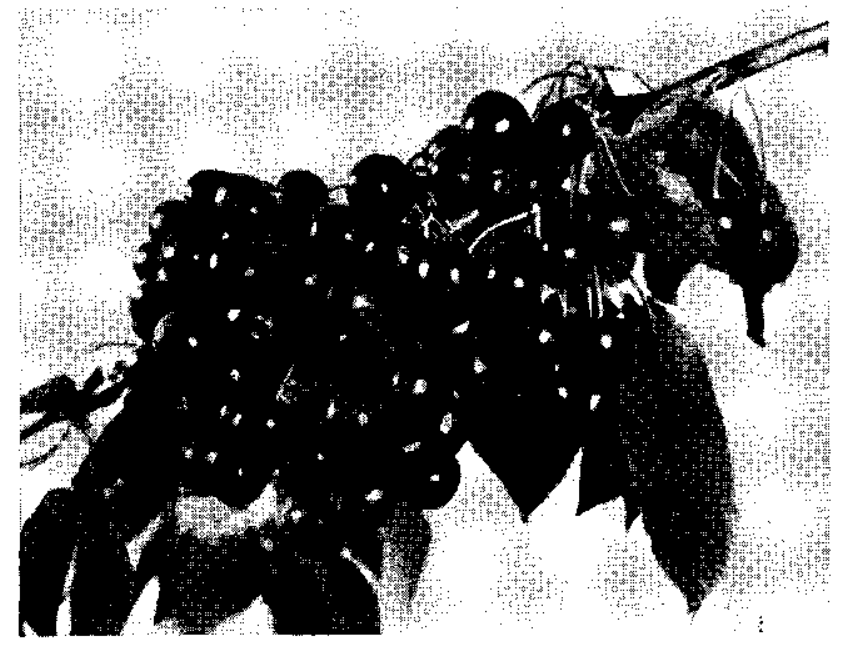

In this selection field 6 trees of each variety are planted in a block. Two of them are permanent trees and spaced at $10 \times 8 \mathrm{~m}$; the rootstock for these permanent trees is F 12/1, an English selection from the Prunus avium, which is said to be very resistant to.bacterial canker, is vigorous and bears fairly early. Between the permanent trees are the filler trees, 2 on seedlings Limburgse boskriek (wild Pr. avium= Mazzard) and 2 on seedlings of $P r$. Mahaleb so that their compatibility with these rootstocks may also be studied. The poor varieties in selection field B are gradually discarded and the good ones are eventually included in variety trials.

In selection field B special attention is paid to characters of hardiness, succulence, juice colour, disease resistance, transport and storage quality, growth habit, precocity, degree of fertility, picking quality and pollination requirements.

Variety trials. The varieties which behave favourably in selection field $B$ are included in commercial trials and, if possible, in variety trials carried out throughout the country (systematic variety trials).

In commercial trials promising varieties from selection field B are distributed among growers in various parts of the country and on various soil types.

To obtain a good impression of the varieties as soon as possible both phases may begin simultaneously.

\section{TRIALS OF COLLECTED VARIETIES}

The collected varieties have not yet been sufficiently studied to say which of them are most suitable for planting. However, some 100 varieties which, according to the literature or some Dutch growers, look promising, have been planted in selection field B. F 12/1 was planted ungrafted, and in 1954 the varieties were grafted on the crown; because the framework branches are formed by $\mathrm{F} 12 / 1$, loss of trees due to bacterial canker is less likely to occur.

It appeared to be difficult to graft upon the rootstock Prunus Mahaleb, and to grow a trunk of it, as was desired. Besides, rooting was very unsatisfactory on heavy 


\section{J. GERRITSEN}

clay. However, from this experiment it was evident that fertility was induced earlier in grafts on Prunus Mahaleb than in those on the $P$. avium seedling. Flowering occurred as early as 1953 and the first fruits were harvested in 1954.

A number of varieties have already been included in variety trials and small-scale commercial trials.

\section{PródUCTION OF PRUNUS AVIUM SEEDLINGS}

Thousands of crosses between P. avium varieties during the years 1950-1954 resulted in 306 seedlings, some of them growing in selection field $\mathrm{A}$, others still being in the nursery. In addition 1202 seedlings of free-pollinated $P$. avium varieties were produced. Some of the seedlings of the 1950 crosses flowered in 1954; in 1955 nearly all of them flowered and the first fruits were picked.

As has already been stated, a great many flowers may have to be pollinated to obtain a few plants. The following examples illustrate the minimum and maximum yields obtained. From 514 flowers of Schneider, pollinated with Early Rivers, 19 seeds but only 1 plant were obtained! On the other hand 398 flowers of Early Rivers pollinated with Wijnkers produced 161 seeds and 46 plants.

From Table 2 it can be seen that in the first place good varieties are needed which ripen a) before Asdonkse; b) between Early Rivers and May Duke, Loen or Mierlose Zwarte; c) after Schneiders Späte Knorpelkirsche. Therefore the following crosses are for the present considered the most important:

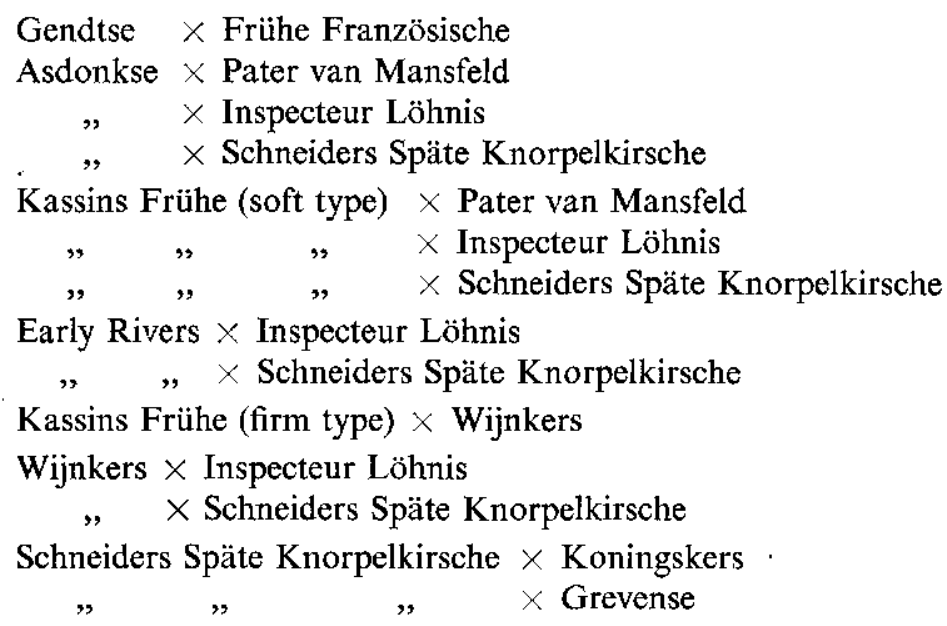

The choice of these varieties as parents has been primarily dependent on their yield, health, taste, resistance to rain and brown rot, and fruit size.

\section{Production of BetTer duke Varieties}

So far May Duke has been about the only representative of the Duke varieties in the Netherlands. In 1946 over $40 \%$ of all the cherries grown in the Netherlands, and $80 \%$ of those grown in the "Betuwe" (the main cherry area of the Netherlands) were May 


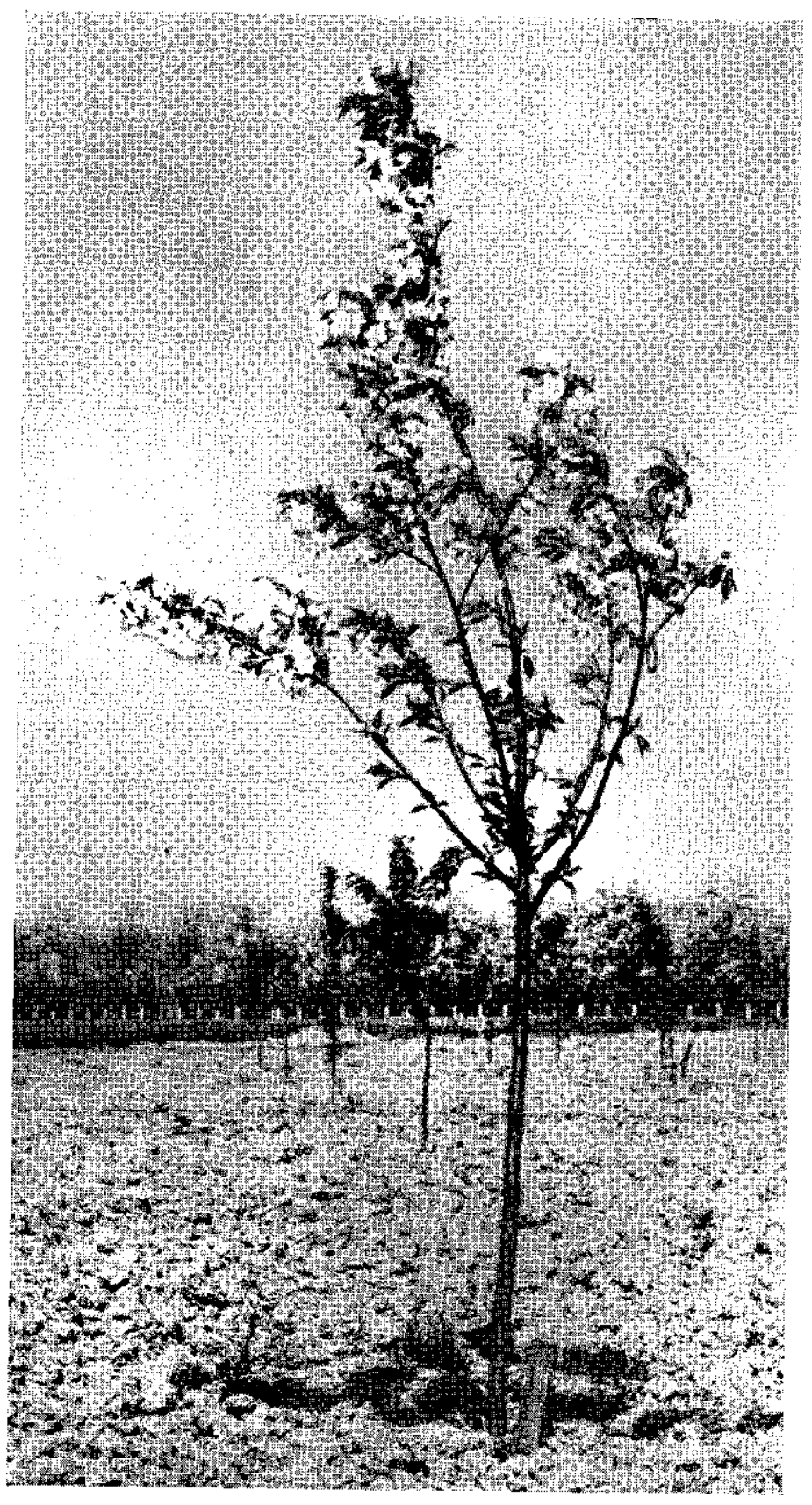

Fig. 4. Prolific bloom in the 3Rd year of a seedling from the cross sour $\times$ SWeet (PR. CERASUS, VAR. MOREL $\times$ PR. AVIUM, VAR. WIJNKERS) 


\section{J. GERRITSEN}

Duke. Indeed, this variety has some very good characters which are partly lacking in the sweet cherries. Its taste is very nice, and it makes a fairly good "filler" tree because of its pyramidal growth and early fruiting. However, its very irregular ripening means several pickings, which increase production costs. In addition the soft texture of the fruits and the occurrence of off-types account for the fact that the May Duke acreage is rapidly diminishing and that only a few May Duke trees are now being planted. Therefore improvement of this variety is very desirable.

To this end the selection of good types of May Duke and the production of seedlings of selfed May Duke trees is being undertaken; in addition crosses of May Duke $X$ Morello, and of May Duke $\times P$. avium varieties are being made. As May Duke is self-compatible, selfing produces good results. The easiest way is to harvest stones of free-pollinated trees in the centre of pure May Duke orchards.

Just like May Duke, Morel is tetraploid. But the latter is a variety of $P$. cerasus, the sour cherry. This variety is being more widely grown for processing. The tree is relatively small, bears well and early, and its fruits are large. This is a great merit, although the fruits are not suitable for fresh consumption because of their high acid content.

The $P$. avium varieties are diploid. In exceptional cases crossing with May Duke may result in a tetraploid hybrid $(7,11)$. In the majority of cases, however, the hybrids are triploid. Therefore, in addition to direct crosses between May Duke and P. avium varieties, crosses of May Duke and tetraploidized $P$. avium varieties are being made. Some foreign tetraploid varieties of $P$. avium have also been used as parents. Other Dukes have not yet been used in crossing, as they are generally considered less suitable as parents.

During the years 1949-1953 some thousands of crosses have produced 276 seedlings which are now growing in selection field $\mathrm{A}$. In addition there are 282 seedlings of selfed May Duke, 11 seedlings of selfed Morel and 85 seedlings of Limburgse Boskriek, a wild growing Prunus avium used as a rootstock for cherries. The latter seedlings were selected in a nursery as they were not quite sweet; probably some of the flowers of the mother had been pollinated by bees carrying pollen of wild sour cherries ( all appear to be triploid).

Flowering occurred as early as 1953; in 1954 out of 546 trees planted the year before, 382 flowered, the majority abundantly. In most combinations, however, the number of fruits produced was very small and those that were produced dropped prematurely and had no embryos. Fruits only set satisfactorily in the cross Morel $\times$ May Duke and reciprocally.

Further experiments on a number of floriferous but non-bearing seedlings showed them to be triploid, as was to be expected (1).

Seedlings derived from the cross May Duke $\times$ Morel should, theoretically, be tetraploid; their fertility proves that this is so. From the first series of observations it was shown that the majority of the fruits are sourer than May Duke, in fact too sour for fresh consumption; time will show whether there are types among these seedlings that can be used either immediately or as parents.

The seedlings of free-pollinated May Duke and Volger generally grow poorly and show many leaf distortions, especially those of Volger. The trees started to flower in 1954 but fruits have not yet been produced. 
Morphologically, it is of interest to note that the growth habit, vigour, shape of leaf and flower, leaf size and inflorescence in many cases are intermediate between those of the parents but occasionally strongly resemble one of the parents (seldom, however, in all characteristics). Types that are entirely sweet, particularly from the viewpoint of growth habit, do not occur. But there are some types that closely resemble Morel or other sour cherries. May Duke and Volger seedlings all closely resemble their parents.

\section{SUMMARY}

1. The area of cherry culture is decreasing in the Netherlands but improvement of the varieties would probably make cherry growing more profitable and more popular again.

2. Many varieties have been collected from the Netherlands and from abroad. Morphological, physiological and cytological investigations were initiated.

3. A first step towards improvement was made by studying the varieties already available in the Netherlands, type selection, and regrouping the list of recommended varieties.

4. Further improvement is expected from studying the imported varieties and from breeding work, which has been started.

\section{SAMENVATTING}

\section{Kersenveredeling in Nederland}

De kers is een vrij belangrijk fruitgewas in Nederland; de teelt van kersen is echter sterk aan het achteruitgaan. Bij onderzoek naar de oorzaken hiervan is gebleken, dat er nog veel mogelijkheden zijn om de kersenteelt rendabeler te maken, o.a. door verbetering van het rassensortiment; besproken wordt, welke eigenschappen een verbetering kunnen ondergaan.

De eerste schrede in deze richting was een bestudering van het Nederlandse sortiment, met als gevolg hiervan grote wijzigingen in de Rassenlijst (tabel 1).

Vele (ongeveer 400) rassen, uit diverse landen afkomstig, werden bovendien verzameld ter nadere bestudering.

Het vaak zeer geringe verschil tussen de rassen heeft een grote naamsverwarring tengevolge gehad; een uitgebreid onderzoek wordt daarom uitgevoerd door Drs. NANNENGA.

In de Meikers komen zeer veel typen voor, evenals onder de Volgers; deze typen zijn niet constant, en gaan vaak in elkander over. Een en ander is voor de teler soms zeer schadelijk. Onderzoek naar de oorzaak hiervan, en over de mogelijkheid de typen te scheiden en constant te houden, is gaande.

De aantallen na kruising verkregen zaailingen waren betrekkelijk gering in verhouding tot de verrichte arbeid, ook na het ontwikkelen van een efficiënte bestuivingstechniek. Om de arbeidshoeveelheid te verminderen, werden van de kruisingsouders planten in potten opgekweekt; deze worden tijdens hun bloei in insectendichte ruimten gebracht, waar bijen de bestuiving uitvoeren (hetgeen zonder castreren mogelijk is door de zelfsteriliteit van de zoete kersen). Ir. Кон ҮАм OH verricht bovendien onder- 


\section{J. GERRITSEN}

zoek naar de mogelijkheid van opheffing of vermindering van de incompatibiliteit tussen te kruisen rassen.

Om ook planten te verkrijgen uit de zaden met een minder goed ontwikkeld embryo, werd tezamen met Drs. BRAAK embryocultuuronderzoek gedaan. Daar het opkweken van de m.b.v. embryocultuur verkregen planten soms moeilijkheden gaf, deed Ir. SMEETS onderzoek naar de invloed van daglengte en temperatuur; tevens dient dit onderzoek om na te gaan of en in hoeverre het tijdstip van het intreden van de vruchtbaarheid vervroegd kan worden.

Voor het kruisingswerk ter verkrijging van betere Meikersen is het van groot belang over tetraploid gemaakte rassen van zoete kersen te beschikken; deze rassen hebben misschien ook nog andere voordelen, zoals b.v. zelffertiliteit. De heer ZEILINGA voert het werk ter verkrijging van tetraploide rassen uit.

Kruisingen tussen verschillende Prunussoorten (kers, pruim, perzik, enz.) worden verricht in samenwerking met Dr. PRAKKEN, Hoogleraar in de Erfelijkheidsleer aan de Landbouwhogeschool.

De verzamelde rassen en door kruising verkregen zaailingen worden geselecteerd op z.g. selectievelden. De selectie-eisen en de toegepaste methodiek worden besproken, en de kruisingsouders genoemd.

De beproevenswaardige rassen worden in rassenproefvelden en praktijkproeven nader op hun waarde voor de praktijk onderzocht. Met veelbelovende zaailingen zal dit ook gebeuren. Een groot aantal zaailingen staat reeds op de selectievelden, en een gedeelte hiervan droeg reeds vrucht.

\section{REFERENCES}

1. Algemene Veredelingsdagen 1952, Med. I.V.T. 50 (1953), 49 pp.

2. BraAk, J.P. and C. J.Gerritsen, The use of embryo culture for cherry breeding (is being prepared).

3. GeRritsen, C. J., Rassenkeuze en rentabiliteit van de kersenteelt. Fruitleelt 40 (1950): 496 en 552.

4. Gerritsen, C. J., May Duke cherries in Holland. Commercial Grower 2989 (1953) : 757-758.

5. Granhall, I., Mutationsforskningens tillämpning på fruktträden. Föreningen för Växtförädling av Fruktträd 18-20 (1950): 1-22.

6. Grubs, N. H., Cherries. London. 1949.

7. KOBEL, F., Lehrbuch der Obstbau auf physiologischer Grundlage. Berlin. 1954.

8. LAMB, R. C., Notes on the inheritance of some characters in the Sweet Cherry. Proceedings of the American Society of Horticultural Science 61 (1953):293-298.

9. LewIs, D., Plant Breeding. Annual Report John Innes Horticultural Institution 44 (1953): 17.

10. LewIS, D. and L. K. CROWE, The induction of self-fertility in tree fruits. Journal of Horticultural Science 29 (1954): 220-225.

11. Schmidt, M., Kern- und Steinobst, Handbuch der Pflanzenzüchtung 7 (1939):1-77.

12. SMEETs, L., A note on the shortening of the juvenile phase in cherry seedlings. Euphytica 5 (1956) : $117-118$. 
35. Kronenberg, Hester $\mathbf{G}$. Nieuwe aardbeirassen in WestEuropa. Juni 1952

36. Hofstra R en M. Keuls. Onderzoek naar de opbrengst van nicotine en Nicotiana rustica (L.) over de jaren 1949-1950. Juli 1952

37. Banga, O. en M. Keuls, Practijkproeven wortelen Amscerdamse Bak 1949-1950. Juli 1952 . . . Uitverkocht

38. Banga, O. en M. Keuls. Practijkproeven zomerwortelen 1949-1950. Juli 1952 . . . . . . . Uitverkocht

39. Kronenberg, H. G. Veredelingswerk met de aardbei op het I.V.T. October 1952 . . . . . . . . . Uitverkochc 40. Floor, J. Proeven met vermeerdering door entstekken. October 1952

$f 1,25$

1. Banga, $\mathbf{O}$. Some factors in the growth rate of red garden beets. November 1952

42. Sneep. J. Practijkproeven met Westlandse Boerenkool 1949-1950 en 1950-1951. December 1952 f 1 ,

43. Een bos enthoutjes. Januari $1953 \ldots \ldots$. . . . f 1,35

44. Banga, 0 . Practijkproeven met Ronde Rode Radijs 1951-1952. Februari 1953 ...... . f 0,65

45. Gerritsen, C. J. De rassenkeuze bij de Walnoot. Maart 1953.

46. Kronenberg, H. G. De veredeling van KleinFruit in de Ver. Staten van Amerika ........

47. Banga, O. en M. Keuls. Practijkproeven met Berlikumer Wortel 1949. April 1953...... f 0,65

48. Gerritsen, C. J. Welke kersen moeten we planten. April 1953

49. Banga, O., M. Keuls en M. Wattel. Practijkproeven met Flakkeese Winterwortel 1950-1951. Mei 1953 .

0. Algemene Veredelingsdagen 1952. Verslag van voordrachten en discussies. Juni 1953 . - i ig.

1. Sneep, J. Practijkproeven met Spitskool 1949-

52. Boom, B. K. Internationaal reglement voor de naamgeving van gekweekte planten ....... $f 0,75$

53. Kronenberg, H. G. en F. Garretsen. Opbrengstproeven met aardbeiklonen. November 1953.

54. Veredelingsdag Groentegewassen 1953. Verslag van yoordrachten en discussies. December 1953 . f 1, -

55. Floor, J. Planten in plastic. Januari 1954 . Uitverkocht 6. Banga, $O$. Taproot-problems in the breeding of root vegetables.

57. Jonema J. R an A Krail Practijeroeven if 0,25 Kool 1950-1951. Juni 1954 . . . . . . . . . f 1,10

58. Jensma, J. R. en A. Kraai. Practijkproeven met Spruit-

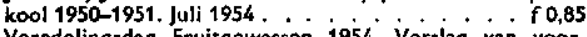

59. Veredelingsdag Fruitgowassen 1954. Verslag van voordrachten en discussies. Augustus 1954 * * $4^{\circ}$; 0,95 60. Kraai, A. The use of Honey-bees and Bumble-bees in
breeding work. September $1954 \ldots . . . .60 .45$ 61. Jensma, J. R. en A. Krazi. Practijkproeven met Witte Kool 1952-1953. Februari 1955 . . . . . . . . f 1,35
62. Banga, O. en J. W. de Bruyn. Selection of Carrocs for Carotene Content. Februari 1955 ...... . f 0.25

63. Kronenberg, H. G. en L. M. Wassenaar. Practijkproeven met aardbeirassen 1952-1954. April 1955 . f 0.90

64. Keuls, M. and J. W. Sieben. Two statistical problems in plant selection. April 1955 . . . . . . . . . f 0.35

65. Banga, 0 . The Institute of Horticultural Plant Breeding. April 1955 ........... f 0.25

66. Banga, 0 . Uienveredeling met gebrujkmaking yan inteelt en herstel door heterosis. Juni 1955 . . . . f 0,30

67. Banga, O. Carrot yield analysis. September 1955 * 0,30

68. Banga, O., J. W. de Bruyn and L. Smeets. Selection of carrots for carotene content. II Sub-normal content at low temperature. September 1955 . . . . . . . . f 0,25

69. Braak, J. P. Effect of temperature and light on June Yellows in strawberries. September 1955..... . f 0,25

70. Banga, $O$. De ontwikkeling van de rassensituatie bij groentegewassen. Oktober $1955 \ldots$..... 0,25

71. Bruyne, A. S. de. Tendenzen in de ontwikkeling van het Nederlandse fruitsortiment. Oktober 1955 . . . 0,40

72. Banga, O. Prakcijkproeven met Knolselderij 1953-1954. November 1955 ............. . f 0,30

73. Floor, J., Proeven met stokken onder waterverneveling. April $1956 \ldots \ldots$. . . . . . .

74. Andeweg, j. M. en J. H. Ruyten. Praktijkproeven met Tomaten 1954-1955. April 1956....... f 0.40

75. Andeweg, 1. M. en A. van Steenbergen. Praktijkproeven met Stoksnijbonen 1953-1954. Mei 1956 . . f 0,35

76. Banga, O. en J. L. van Bennekom. Praktijkproeven met Ronde Witpunt Radijs 1953-1954. Mei 1956. . . f 0,55

77. Smeets, L. and Hester G. Kronenberg. Runner formation on strawberry plants in autumn and winter. Smeets, L. Runner formation on strawberry plants in autumn and winter. II. Influence of the light intensity on the photoperiodical behaviour. Juni 1956... f 0,30

78. Smeets, L. Influence of the cemperature on runner production in five strawberry varieties. Juni 1956 . . . f 0,25

79. Smeets, L. and L. M. Wassenaar. Problems of heat spo in Fragaria vesca $L$, when indexing strawberry selections for viruses. Juni 1956

80. Banga, O. and J. W. de Bruyn, Selection of carrots for carotene content. III Planting distances and ripening equilibrium of the roots. Juni 1956 . . . . . . . . 0,35

81. Banga, $O$. International conference on the improvement and on the standardization of vegetable varieties at Wageningen, Netherlands, on August 26 and 27, 1955. August 1956 . . . . . . . . . . f 0,75

82. Floor, J. Proeven met vermeerdering van houtige gewassen. September 1956 ......... f 0,80

83. Gerritsen, C. J. Improvement of the cherry varieties used in the Netherlands. Oktober $1956 \ldots$..... f 0,35

\section{PERSBERICHTEN UITSLAGEN PRACTIJKPROEVEN}

10- 3-'50. Uitslag Practijkproeven Wortel Berlikumer 1949.

29-11.'50. Uitslag Practijkproeven Bak-en Zomerwortelen 1949-1950.

29-11-'50. Uitslag Practijkproeven Platronde en Ronde Kroten 1949-1950.

22-12-'50. Uitslag Practijkproeven Pronkbonen 1950.

11- 3-51. Uieslag Practijkproeven Westlandse Boerenkool 1949-1950.

3. 9.51. Uitslag Praccijkproeven Spitskool 1950-1951.

7-12-'51. Uitslag Practijkproeven Flakkeese Winterwortel 1950-1951.

23- 1-'52. Uitslag Practijkproeven Vroege en Herfst Rodekool 1950-1951.

31- 3-52. Uitslag Practijkproeven Spruitkool 1950-1951.

4-11-52. Uitslag Practijkproeven Ronde Rode Radijs 1951-1952.

4-11-'52. Uitslag Practijkproeven Vroege Rijspeulen 1951-1952.

25-11-'52. Uitslag Practijkproeven Lange Kroten 1951-1952.

23- 1-'53. Uitslag Practijkproeven Radijs Ron's Scharlakentode Extra Kortloof 1951-1952.

13- 5-'53. Uitslag Practijkproeven Bewaar Rode Kool 1951-1952.

10- 9-'53. Uitslag Practijkproeven Vroege Witte Kool 1952-1953.

18-12-'53. Uitslag Practijkproeven Herlst Witte Kool 1952-1953.

3- 6-'54. Uitslag Practijkproeven Bewaar Witte Kool 1952-1953.

17-11-'54. Uitslag Practijkproeven Stoksnijbonen 1953-1954

2-12.'54. Uitslag Practijkproeven Ronde Rode Witpunt Radijs 1953-1954.

12. 2-'55. Uitslag Practijkproeven Knolselderij 1953-1954.

1- 9-55. Uitslag Practijkproeven Vroege Groene Savoye Kool 1954-1955.

14-11-'55. Uitslag Practijkproeven Tomaten 1954-1955.

27 12-55. Uitslag Practijkproeven Witlof vroege trek 1954-1955.

2-3-'56. Uitslag Practijkproeven Witlof middelvroege trek 1954-1955.

5-3'56. Uitslag Practijkproeven Schorseneren 1954-1955.

28- 5-56. Uitslag Practijkproeven Savoye Kool 1954-1955.

28- 5-'56. Uitslag Practijkproeven Witiof koude kuil en meilof 1954-1955.

30- 7-56. Uitslag Practijkproeven Tuinbonen 1955-1956.

1. 9-'56. Uitslag Praktijkproeven Amsterdamse Bakwortel 1955-1956

1- 9-'56. Uitslag Praktijkproeven Vroege Rode Kool 1956

1- 9-'56. Uitslag Praktijkproeven Platronde Kroten 1955-1956

Zijn geplaatst in diverse tuinbouwbladen. 


\section{RASSENLIJSTEN ${ }^{1}$ ) \\ UITGEGEVEN DOOR HET INSTITUUT VOOR DE VEREDELING \\ VAN TUINBOUWGEWASSEN}

Achtste Beschrijvende Rassenlijst voor Fruit. 1957. . f 1,75 \begin{tabular}{|l} 
Achtste Beschrijvende Rassenlijst voor Groentegewas- \\
sen. 1956. Redacteur Dr. O. Banga . . . . . . 1,75
\end{tabular}

\section{JAARVERSLAGEN ${ }^{1}$ )}

VAN HET INSTITUUT VOOR DE VEREDELING VAN TUINBOUWGEWASSEN

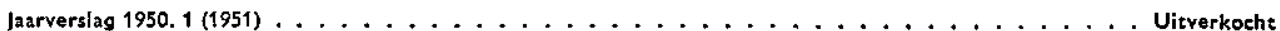

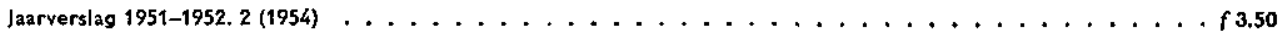

\section{PUBLIKATIES VAN HET INSTITUUT VOOR DE VEREDELING VAN TUINBOUWGEWASSEN IN ANDERE ORGANEN OF IN BOEKVORM EVENTUEEL IN'SAMENWERKING MET ANDERE INSTELLINGEN ${ }^{\text {?) }}$}

De publikaties, waarvan prijs èn uitgever worden vermeld zijn verkrijgbaar in de boekhandel. Overigens wende men zich cot de opgegeven bronnen of tot de bibliotheek van het I.V.T.

Elzenga, G. De selectie van Angelica-wortel op wortelgewicht en vluchtige oliegehalte in verband mec milieu-factoren. V.N.K.-Nieuws $1955: 34-39,42-47$

Gerritsen, C. J. De selectie van (okker)-noten. Dendrologisch Jaarboek 1954: 40-43.

Jensma, J. R. Mei in Mechelen. Groenten en Fruit 10, 1955 1292.

Floor, J. en P. A. Wezelenburg. Planten in plastic. Uitg. I.V.T. Juni 1955, 10 p. $10,25$.

Banga, $\mathbf{O}$. De plantenveredeling als factor in de strijd om het bestaan. Extra nummer Landbouwkundig Tijdschrift Me 1955 en Zaadbelangen 9, 1955: 173-174, 187-188.

Kronenberg, H. G. Ervaringen met aardbeirassen in 1955. Groenten en Fruit 11, 1955: 138.

Elzenga, G. Het kweken van plantmateriaal van Valeriaan. V.N.K.-Nieuws 1955: 70-72.

Jensma, J. R. Is spits + vroeg + sroen = Vroege Groene Spitse? Groenten en Fruit 11, 1955: 221

Elzenga, G. Digitalis lanata. V.N.K.-Nieuws 1955: 87-91.

Boom, B. K. Notes on culcivaced plants. Acta Botanica Neerlandica 4, 1955: 167-171.

Banga, O. Het XIVe Internationale Tuinbouwcongres. Zaad belangen 9, $1955: 232-233$.

Gaag, H. C. v.d. Het kweken en het gebruik van vleesvliegen bij het veredelingswerk. Zaadbelangen 9, 1955: 233-236.

Elzenga, G. Veredelingsproblemen bij Angelica archangelica. Meded. Dir. Tuinbouw 18, 1955: 748-752.

Floor, J. Problemen bij de selectie van rozenonderstammen. Meded. Dir. Tuinbouw 18, 1955: 706-710.

Kronenberg, H. G. (I.V.T.) en J. J. Doesburg (I.B.V.T.). Meer aandacht voor het vitamine-C-gehalte van zwarte bessenrassen. Groenten en Fruit 11, 1955: 365. De Fruitteelt 45, 1955: 869 .

Banga, 0 . De benaming van rasser. Zaadbelangen 9, 1955: 247-248.

Boom, B. K. Coconeaster wardii en verwante soorten. De Boomkwekerij 11, 1955: 3.

Gerritsen, C. J. Zit er wat in de teelt van hazelnoten? Oe Fruitreelt 45, 1955: 865 .

Kronenberg, H. G. Aardbeien. Wat moeten we toch planten? De Fruitreelt 45, 1955: 866-867.

Gerritsen, C. J. Gaat $U$ kersen planten? De Fruitteelt 45, 1955: 909-910.

Burg, J. P. L. L. A. en G. Elzenga. Rapport over een studiereis aangaande de teelc en verwerking van geneeskrachrige en aromatische gewassen in Duitsland en Frankrijk $(16 \mathrm{t} / \mathrm{m}$ 31 augustus 1955). V.N.K.-Nieuws, september 1955: 92-99.

Boom, B. K. Sorbus pratti en S. koeneana. De Boomkwekerij 11, 1955: 27 .

Elzenga $G$. Het rooien van de wortels van Angeliea en $V$ aleriaan. V.N.K.-Nieuws, november 1955: 110-111

Elzenga, G. Pepermunt opnieuw inplanten. V.N.K.-Nieuws, november 1955: 112.

Boom, B. K. Vraagstukken rondom het Cotoneaster-sortimen. De Boomkwekerij 11, 1955, 41-42

Jensma, J.R. Rassenkeuze bij bloemkool. Groenten en Fruit $11,1956: 721$.

Bruyne, A. S. de. Nieuwe appelrassen tot lames Grieve. De Fruitwereld 1, 1956; no 4; 8-9.

Boom, B. K. Cercidiphyllum. De Boomkwekerij 11, 1955: 27.

Broertjes, C. Reactie op vraagstukken rondom het Cotoneascersortimenc. De Boomkwekerij 11, 1956: 67-68.
Broertjes, C. Veredeling op ziekteresistentie bij rozen. De Boomkwekerij 11, 1956: 73.

Boom, B. K. Acer platanoides, reitenbach' en ,rubrum' De Boomkwekerij 11, 1956: 74.

Bruyn, J.W. de. De exportcontrole van kruiden in 1955. V.N.K.-Nieuws, januari 1956: 134-135.

Boom, B. K. Buxus, buksus of buks. De Boomkwekerij 11 1956: $80-81$

Boom, B. K. Drie nieuwe wilgen. De Boomkwekerij 11, 1956: $81-82$.

Boom, B. K. Enkele bontbladige bomen. De Boomkwekerij 11, 1956: 88

Boom, B. K. Een nieuwe monographie over hec geslacht Philadelphus. De Boomkwekerij 11, 1956: 96-97.

Gerritsen, $c$. J. Zal de noot een deugd worden? De fruitwereld 1, 1956; no. 14:5.

Banga, $O$. Enkele opmerkingen naar aanleiding van een internacionale conferencie. Zaadbelangen 10, 1956: 101-102.

Kronenberg, H. G. Strawberry growing in the Necherlands. American Fruit Grower 76, 1956: no. 4: 77.

EJzenga, G. Lobelia inflata. V.N.K.-Nieuws, mast 1956: 163166.

Boom, B. K. Variëteic en cultivar. De Boomkwekerij 11, 1956: 112-113.

Andeweg, J. M. Vroegrijpende moneymaker's. Zaadbelangen 10, 1956: 145.

Boom, B, K. Verwarring over de plantennamen. Vakblad voor de Bloemisterił 11, 1956: 130-131.

Gijsbers, J. W. Ruimtebesparing bij de opberging van dia's en nejatieven. Meded. Dir. Tuinbouw 19, 1956: 298-300 oom, B. K. Over een verzameling prijscouranten. De Boomkwekerij 11, 1956: 128-129.

Boom, B. K. Een Amerikaan over Boskoop. De Boomkwekerij 11, 1956: 130

Huyskes, J. A. Klauwenselectie bil asperges geeft goede resulcaten. Boer en Tuinder (Land en Vee) 10, 1956; no. 482: 17

Koot, Y, v, en 1. M. Andewez. De groenteteelt in Amerika. s-Gravenhage, C.O.P., 1956. 149 blz. f 7,00.

Banga, $\boldsymbol{O}$. Kweker en overheid in de sector groentezaden. Zaadbelangen 10, 1956: 189-190.

Kho, Y. $\mathbf{O}$. Opbrengstyermindering en kiemkracheverlaging van wortelzaad als gevolg van aantasting door wantsen. Zaadbelangen 10, 1956: 193-194.

Elzenga, G. Digitalis lanata Ehr. Y.N.K.-Nieuws 1956: 167-170, 193-199.

Andeweg. J. M. Rationalisatie en rassenkeuze. Groenten en Fruit 12, 1956: 111.

Kho, Y. O. en 1. P. Braak. Opbrengstvermindering en kiemkrachtverlaging van wortelzaad als gevolg van aantasting door wantsen. Meded. Dir. Tuinb. 19, 1956: 440-445.

Kronenberg, H. G. Praktijkproeven met aardbeien in 1956. De Tuinderij 36, 1956, no 33: 1-3. Groenten en Fruit 12, 1956: 177 .

Floor, J, en P. A. Wezelenburg. Stekken onder plastic. De Boomkwekerij, 11, 1956: 174-175.

Terpstra, $W$. Some factors influencing the abscission of debladed leaf petioles. Acta Botanica Neerlandica 5, 1956: 157-170

Bruyne, A. S. de. Trends and developments in Dutch varieties. The Commercial Grower 1956, no 3165: 419-422.

1) Zolang de voorraad strekt kunnen deze publikaties f́ranco worden toegezonden, na ontvangst van het vermelde bedrag op giro no. 425340 van het Instituut voor de Veredeling van Tuinbouwgewassen, 5. L. Mansholtlaan 15 te Wageningen onder vermelding van wat verlangd wordt; ook bestaat de mogelijkheid deze publikaties uit de bibliothoek van het I.V.T. te lenen.

*) Eerder verschenen publikaties xijn vermeld achterin in de Mededelingen nos $1 \mathrm{t} / \mathrm{m} 70$. 